\title{
E-BANKING CHALLENGES AND FUTURE PROSPECTS-A CASE STUDY OF MYSORE CITY
}

\begin{tabular}{|c|c|}
\hline Mr. Shivakumar, & Dr.NBabithaThimmaiah, \\
Assistant Professor, Department of MBA, & Assistant Professor, Department of MBA, \\
VTU PG Center, Mysore-29, & VTU PG Center, Mysore-29, \\
Email: hulsoor.shiv06@gmail.com, & Email: babitha.vvce@gmail.com, \\
Mobile: 9164856510 & Mobile: 8050230578 \\
\hline
\end{tabular}

\begin{abstract}
E-banking establishes an electronic network of banking services and the need for these alternative networks has been established long back by the foreign banks.But India is still in the beginning stages of e-banking.Technology and competition have changed the face of banking business. So, it is likely to bring lot of opportunities and challenges to the new mode of banking business.It benefits banks as well as the customers. Today, both banker and customers are facing challenges like data management risk, safety and legal aspects. Therefore, the present paper has focused on the need of e-banking, and its present status in Mysore city. It also covers challenges and future prospects of e-banking in Mysore.
\end{abstract}

Key words: e-banking, Credit cards, security regulatory framework, Globalization

\section{PREAMBLE}

Indian banking industry was domestic oriented until 1969. Banking business was confined to only accepting deposits and lending loans. Now in this technology era banking is being called as innovative banking. Using the information technology in delivering the banking business is the need of the day. Without the help of technology services like mobile banking, ATM, debit card and internet are impossible. It shows most of the banking products are of more technology oriented. The initiation of EBusiness accompanied with innovation in technology and globalization is constantly forcing the businesses organization to redefine their business operations in terms of restructuring business models. Financial institutions mainly the banking sector is currently in a transition phase. The banks have put themselves in the World Wide Web to gain advantage of the internet's power and reach, to cope with the accelerating pace of change of business environment. This transition of banking business has created new mode of operation called E-Banking.

\section{E-Banking:}

E-banking is using of electronic technology in serving the customers at their office or home by banks. It is also called as home banking, internet banking, virtual banking etc.In other words, it is a process of banking services and products through electronic channels such as telephone, internet, cell phone etc. 


\section{Electronic Bankingand Its Uses:}

It includes:Automated Teller Machines, Electronic Fund Transfers, Debit cards and Credit cards, Tele Banking, Mobile Banking E-banking is the banking of new era. The term Internet Bankingor E-Banking Internet both are used as supplement. Makingbanking services available to wholesale andretail customers, through an electronic mode iscalled e-banking. In other words E-Banking refers to the bankingoperations, which is done over World Wide Web. E-banking isthe outcome of technological advancement and competition. Infact, banks have been using electronic and telecomnetworks for providing a wide range of value added productsand services. The devices have been telephone, personalcomputers including Automated Teller Machines (ATM). Thedelivery mode has been direct dial up connections, privateand public networks. To this latest edition of e-banking arebeing added e.g. Internet banking and mobile banking. The use of ATM's lead to the concept of 'anywhere' and'anytime' banking. Through the use of ATM cards, anyone canoperate his bank account to withdraw money from any of bank'sATM available at the nearest site. This had brokendown the time and space barrier. The new banks are providingsome of the services exclusively through ATM's.
Electronic Banking also known as Internet Banking is the latest in the series oftechnological wonders of the recent past. ATMs, Tele-Banking, Internet Banking, Credit Cardsand Debit Cards have emerged as efficient delivery channels for banking products.Banks know that the Internet opens up new horizons for them and moves them from local to global market. IB refers to systems that enable bank customers to get access to their accountsand general information on bank products and services through the use of bank's website, without the problems of sending faxes, signatures andtelephone confirmations. It is the types of services through which bank customers can requestinformation and carry out most retail services such as balance enquiry, accounttransfers, bill-payment, etc., via telecom network without leaving theirhome/office. It also provides universal connection from any location worldwide and isuniversally accessible from internet linked computer. IT developmentsin the banking sector have speed up communication and transactions for clients. It is vital toextend this banking feature to clients for maximizing the advantages for both clients and serviceProviders. 


\section{REVIEW OF LITERATURE:}

Uppal and Chawla(2009) found that the customers of public sector, private sector and foreign banks in Ludhiana district of Punjab are interested in e-banking services, but at the same time are facing problems like inadequate knowledge, poor network, lack of infrastructure, unsuitable location, misuse of ATM cards and difficulty to open an account. Sharma (2009) opined that the trend towards electronic delivery of banking products and services is occurring partly as a result of consumer demand, and partly because of the increasing competitive environment in the global context. Haq\& Khan (2013)analysed the challenges and opportunities in the Indian Banking sector. The study showed that only 28 per cent banking clients were using internet banking after evaluating the population characteristics. It found that there was no significant relationship in between age and use of cyber banking. It also depicted that there is no relation in between gender and the adoption of internet banking. It observed that qualification in terms of education and income of the respondents were playing the role in the acceptance of online banking. The study suggested that it is the need of time that financial literacy of the users should be increased through various programs which should be run by banks to increase the awareness of internet banking.

\section{SCOPE OF THE STUDY:}

This paper covers the present status of ebanking, challenges and future prospects in Mysore city.From the existing literature reviews it shows that only researches are available on e-banking and no studies have been conducted to identify the current status of e-banking and its challenges, future prospect in Mysore. In this regard, the present paper would benefit both banker and customer.

\section{OBJECTIVES OF THE STUDY:}

- To study the needs and benefits of ebanking in Mysore,

- To study the challenges and opportunities of e-banking in Mysore.

\section{RESEARCH METHODOLOGY:}

The present study is descriptive in nature. The data collected for the study is through primary data with the structured questionnaire and secondary data RBI report, journals, articles, newspapers etc.

Sample size: The Sample size for the study is One Hundred,

Sampling method: Convenient sampling method is being used for data analysis and interpretation. 
Asia Pacific Journals

ANALYSIS OF THE STUDY:

\section{Are you using e-banking ?}

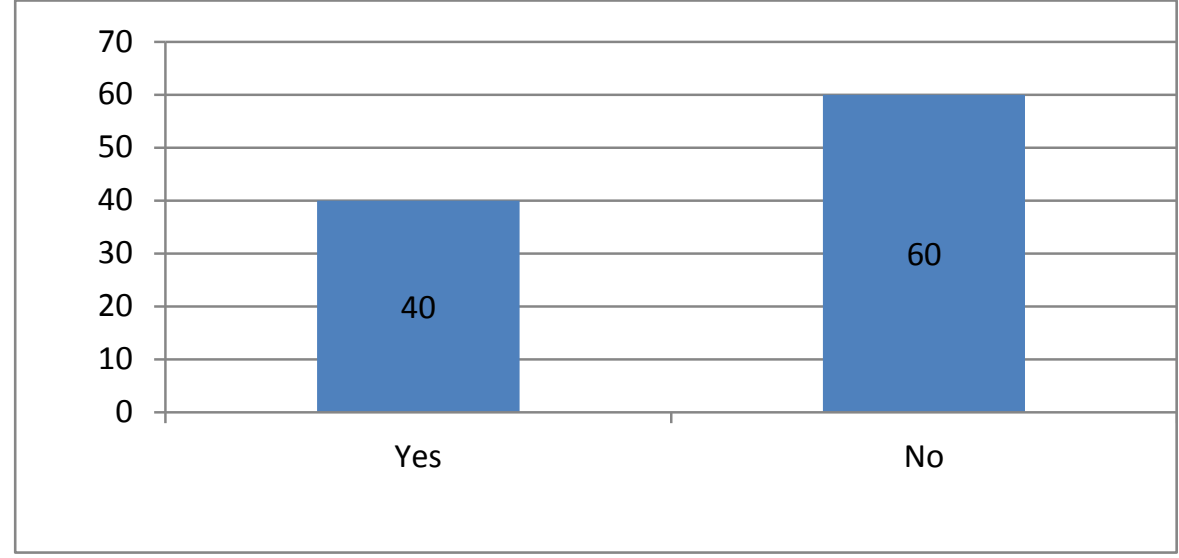

The above graph shows out of 100

banking services. Only 40\% respondents are respondents $60 \%$ respondents are not using ee-banking users. It can be inferred lack of awareness has led to less usage of e-banking.

2. Since how long you have been using e-banking ?

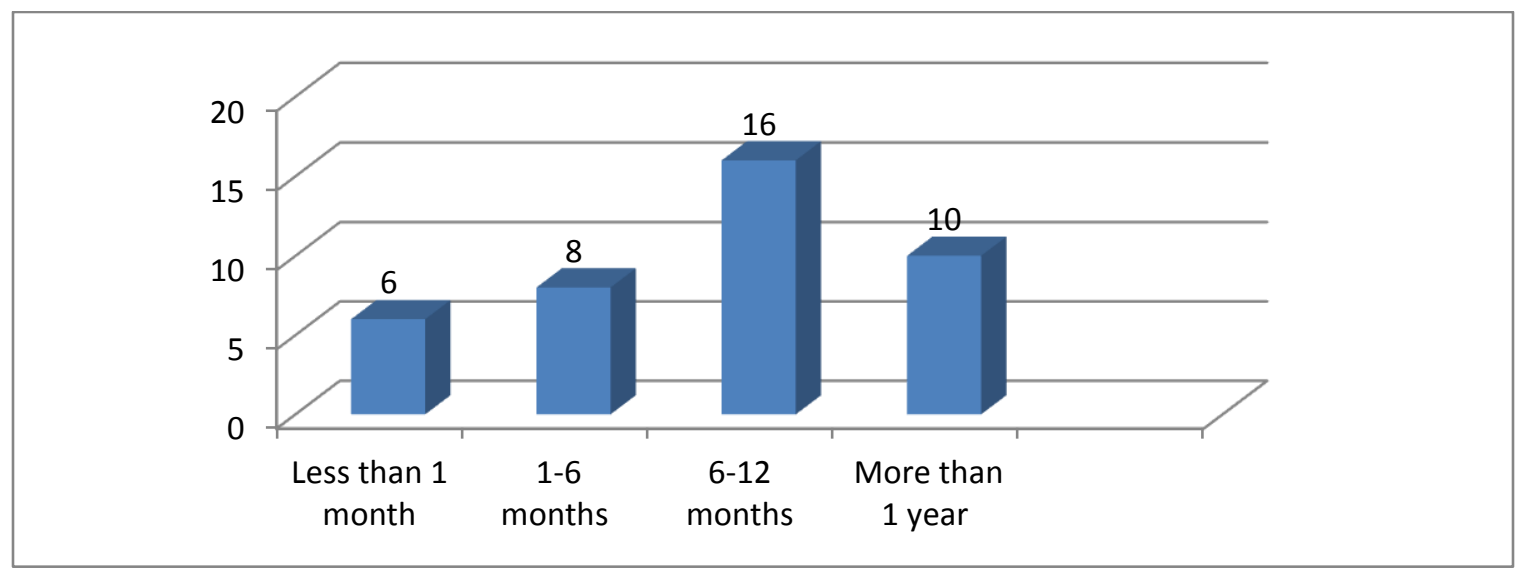

The above graph shows only $40 \%$ 1 year. It can be inferred that less people are respondents are using e-banking services aware of e-banking services.

since more than 6 months and $25 \%$ more than

\section{What are the reasons for using e-banking ?}

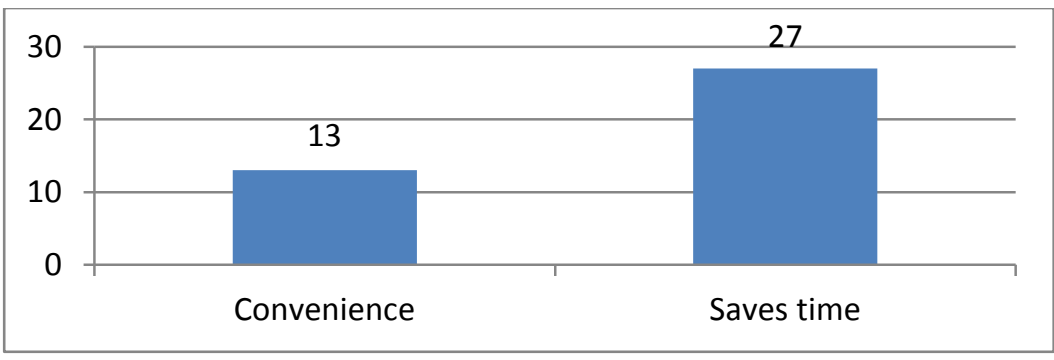


The above graph shows majority of the respondents(68\%) are using e-banking services for saving time and $32 \%$ respondents say convenience. It can be inferred that saving time is priority of the customers.

\section{How comfortable are you in using e-service?}

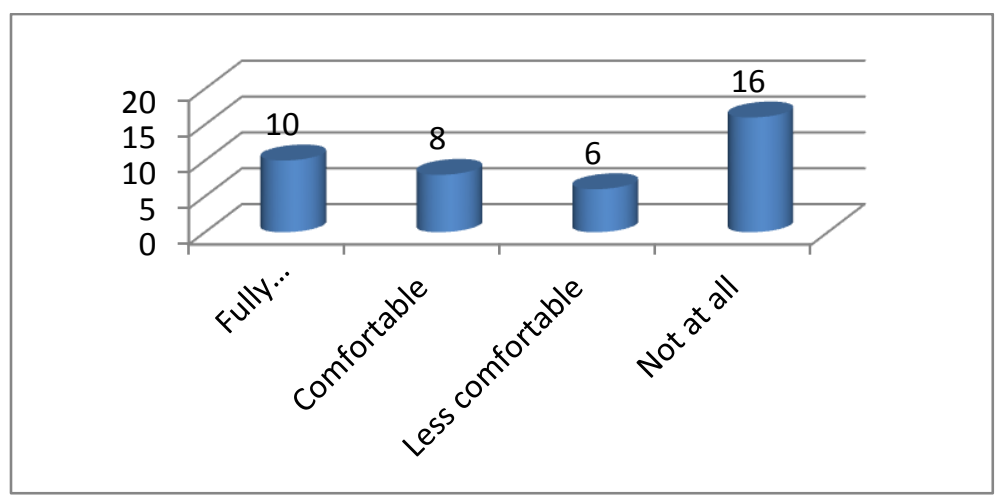

The above graph shows majority of the that there is a lack of technical knowledge respondents $(40 \%)$ are not at all comfortable among the respondents.

using e-banking services. It can be inferred

\section{How often do you use e-services?}

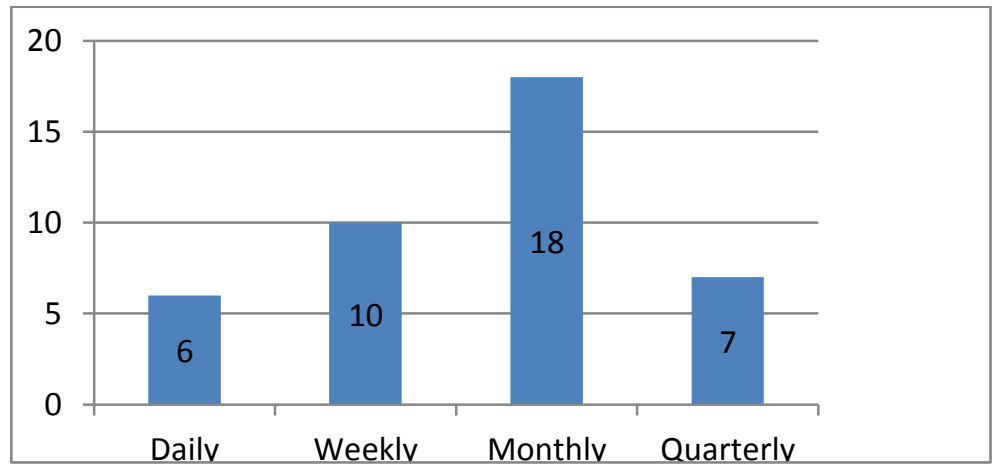

in a month. It can be inferred that the usage of

The above graph shows nearly $45 \%$ of the e-services by the respondents are very respondents are using e-banking services once minimal.

\section{What are the services do you prefer online?}




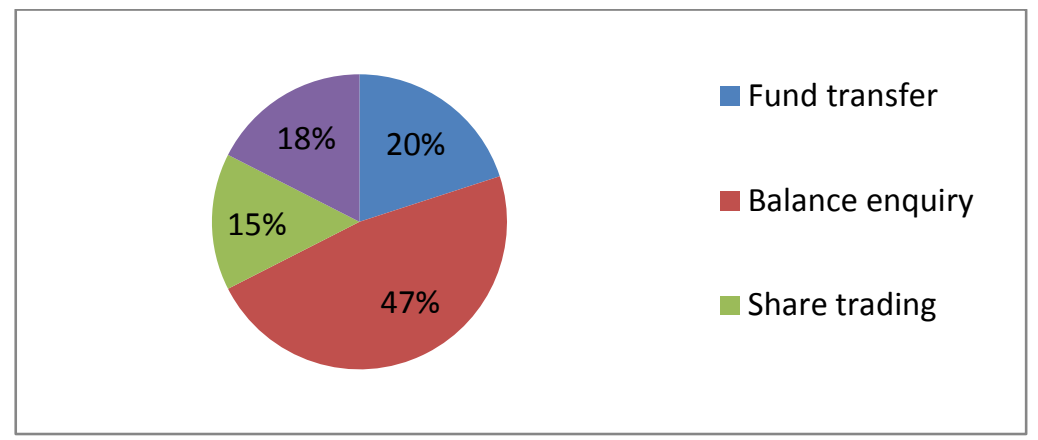

The above graph shows $48 \%$ respondents use

balance. It shows majority prefer using eonline banking services for checking account

\section{Which online feature do you use regularly?}

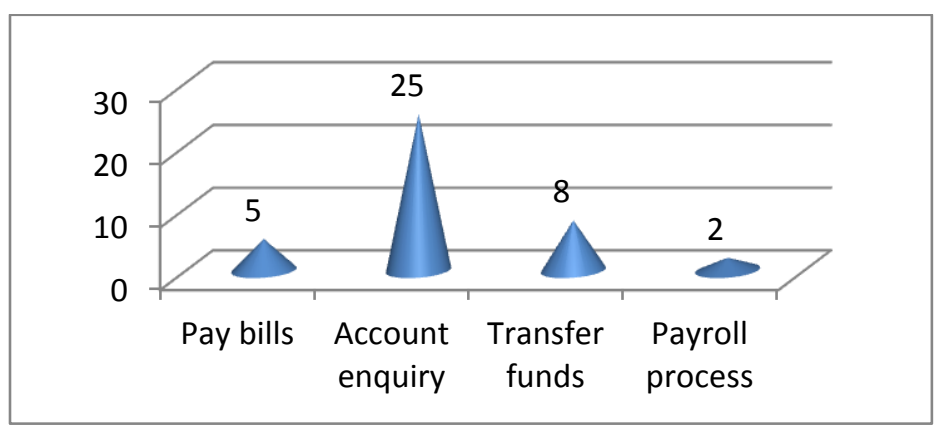

be inferred that respondents are risk averse

The above graph shows majority of the with the other services of e-banking like pay respondents $(63 \%)$ are using online banking bills, transfer funds etc.

services regularly for account enquiry. It can

\section{Do you prefer mobile phone banking?}

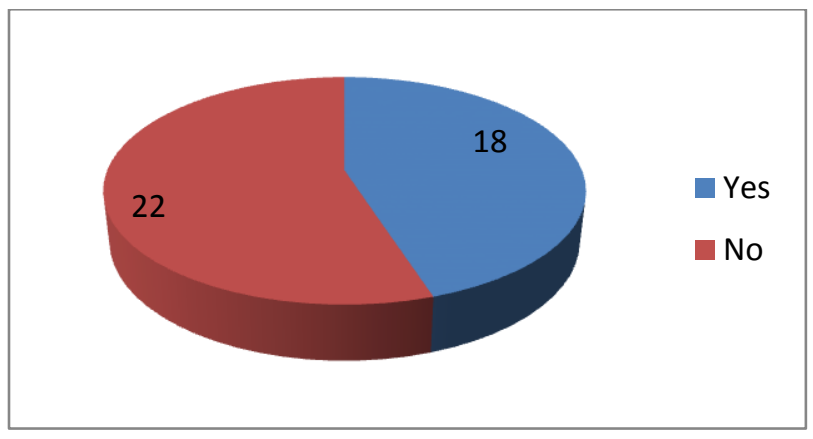


The above graph shows that more than 50\%

of the respondents are not using mobile banking at all. It indicates majority of the respondents are less aware of mobile banking.

\section{Rank these-services based on safety and security?}

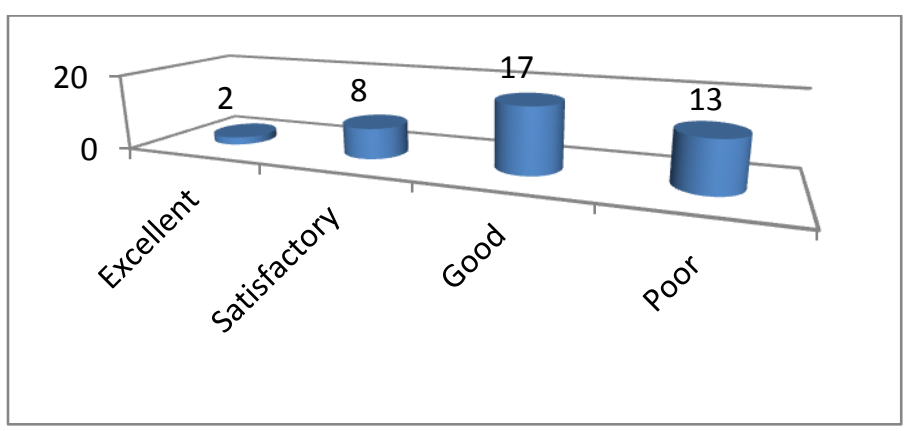

The above graph shows nearly $43 \%$

respondents saygood about the safety of e-

banking. It indicates nearly 33\%respondents

have more concern about the safety and

security on e-banking services.

\section{What are the e-banking servicesyou use most?}

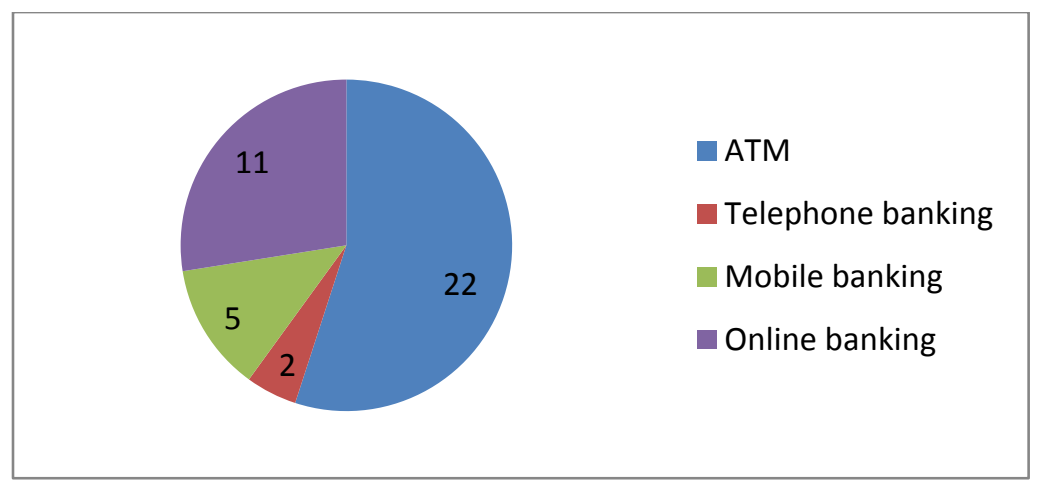

The above graph shows55\%respondents use

ATMs for their banking services. It can be

inferred that majority of the people are

comfortable using e-banking only ATM services. 


\section{CHALLENGES OF E-BANKING:}

Implementation of new technology: There is a need to have an adequate level of infrastructure and human capacity building before the developing countries can adopt new technology for their requirements. In developing countries, especially in city like Mysore many consumers either do not trust or do not access to the necessary infrastructure to be able to process e-payments.

Joint effort: In developing countries, in the past, most e-finance initiatives have been the result of joint efforts between the private and public sectors. If the public sector does not have the necessary resources to implement the projects it is important that joint efforts between public and private sectors with the help of multilateral agencies like the World Bank.

Customer is king: In today's competitive world, customerssatisfaction is a major challenge for the banking sector because customers have alternative choices in various types of services provided by banks.

Personnel services: In present times, banks are to provide several services like social banking with financial possibilities, computerization and innovative mechanization, better customer services, effective managerial culture, internal supervision and control, strong organization culture etc. Therefore, banks must be able to provide complete personnel service to the customers.

Stiff Competition: The nationalized banks and commercial banks have the stiff competition from foreign and new private sector banks. Competition in banking sector brings various challenges before the banks such as product positioning, innovative ideas and channels, new market trends etc at managerial and organizational part.So, the banks in Mysore need to be manage assets and contain risk. Banks are decreasing the use of manual power and increasing the machine powerto enhance their efficiency.

Managing Technology: Developing or acquiring the right technology, deploying it optimally and then leveraging it to the maximum extent is essential to achieve and maintain high service and efficiency standards while remaining cost effective and delivering sustainable return to shareholders. Using the latest technology will give the competitive advantage in managing technology is therefore, a key challenge for the banks in Mysore.

\section{OPPORTUNITIES:}

Rural Markets: Contributing to $70 \%$ of the total population in India is a largely untapped 
ELK

Asia Pacific Journals

market for banking sector. In all urban areas banking services entered but only few big villages have the banks entered. So the banks must reach in and around Mysore.

Better Customer Service: Worthy customer services are the best brand ambassador for any bank for growing its business. Every engagement with customer is an opportunity to develop a customer trust in the bank.

Online Banking: It is clear that online finance will pickup and there will be increasing convergence in terms of product offerings banking services, insurance, loans, based on the data warehousing and data mining technologies. Retail Banking: Recently banks have adopted customer segmentation which has helped in customizing their product folios properly. Thus retail lending has become a major focus area particularly in respect of financing of consumer durables, housing, automobiles etc. Since Mysore being semi urban city retail banking has huge scope.

\section{FUTURE PROSPECT:}

Compared to banks in urban cities, banks in semi urban city like Mysore offering online services still is in a beginning phase. For online banking to reach a mass, there should be sufficient number of users and the sufficient infrastructure. The 'Infinity' product
ELK Asia Pacific Journals - Special Issue

ISBN: 978-81-930411-5-4

of ICICI Bank Ltd. gets only about 30,000 hits per month, with around 3,000 transactions taking place on the Net per month through this service. Though various security options like line encryption, branch connection encryption, firewalls, digital certificates, and automatic signoffs are being looked at; there is as yet no Certification Authority in India offering Key Infrastructure which is absolutely necessary for online banking. So, despite many challenges ebanking services in Mysore city are slowly stepping into the next stage. In-order for the success of e-banking services in Mysore proper infrastructure needs to be set-up. The Department ofTelecommunications (DoT) is moving fast to make available additional bandwidth, with that Internet access will become much faster in the future.

The proposed setting up of a Credit Information Bureau for collecting and sharing credit information on borrowers of lending institutions online would give a fillip to electronic banking. The recommendations of the Vasudevan Committee on Technological Up gradation of Banks in India have been circulated to banks. In this background, banks are taking a step for technological up gradation on a large scale. 


\section{CONCLUSION:}

E-banking provides a high level of convenience for managing one's finances even from home or office. However, it continues to through challenges on the financial security and personal privacy in a city like Mysore. Thus, if anyone using the ebanking services he/she should be aware of the risk associated with it. Awareness of the risks and problems enables them to take precautions for a more secured online banking experience.Since Mysore being a pensioners paradise and slowly IT companies are flouring into it.Creating awareness on usage of e-banking would help the banks in enhancing their business.

The concept of e-banking is still evolving. Several initiatives have been taken by RBI and government for smooth functioning of ebanking in India.The RBI has also taken the steps to upgrade the technology from both regulators and supervisors front.

\section{References}

- Annual reports of Reserve Bank of India, www.rbi.org.in

- Chau, P \& Lai, V., "An Empirical Investigation of the Determinants of User Acceptance of Internet Banking”, Journal of organizational Computing and Electronic Commerce, Vol. 13, No. 2, pp 123-145.
- Daniel, E. (1999), "Provision of electronic banking in the UK and the Republic of Ireland", International Journal of Bank Marketing, Vol. 17, No. 2, pp. 72-82.

- Kamakodi, N. and Ahmed Khan, M. B. (2008), "Customer expectations and service level in E-banking Era: An empirical study". The ICPAI university journal of Bank Management, Vol. VII, No.4, pp. 5070 .

- Kumar, R. andSinha A. B. (2009), "An overview of E-banking in India", Professional banker, October issue, pp. 35-37.

- Dheenadhayalan, V. (2010), "Automation of Banking sector in India", Yojana, February, pp.32-40.

- Mavri, M \&loannou, G., “Consumer's perspectives on Online Banking service", International Journal of Consumer Studies, Vol. 30, No. 6, pp 552-560. 